\section{VIOLATIONS OF HUMAN RIGHTS, USE OF CHEMICAL WEAPONS AND THE PHENOMENON OF "NON-STATE ACTORS": A REFLECTION ABOUT THE U.N. SECURITY COUNCIL RESOLUTIONS RELATED TO SYRIA*}

\author{
VIOLACIONES DE LOS DERECHOS HUMANOS, USO \\ DE ARMAS QUÍMICAS Y EL FENÓMENO DE ACTORES \\ NO ESTATALES: UNA REFLEXIÓN ACERCA DE LAS \\ RESOLUCIONES DEL CONSEJO DE NACIONES UNIDAS \\ EN RELACIÓN A SIRIA \\ VIOLAÇ̃̃O DOS DIREITOS HUMANOS USA DE \\ ARMAS QUÍMICAS E O FENÔMENO DE ATORES \\ NÃO ESTATAIS: UMA REFLEXÃO ACERCA DAS \\ RESOLUÇÕES DO CONSELHO DE SEGURANÇA DA \\ ONU EM RELAÇÃO À SÍRIA
}

\begin{abstract}
The study suggests a reflection on the UN Security Council resolutions issued between 2013 and 2015 about the conflict in Syria. It offers a critical analysis of the various issues covered by the Security Council, mainly the related to the violation of human rights, the use of chemical weapons and terrorism. The analysis takes into account the main doctrinal theories of international law related to the three main arguments treated with a reflection oriented to the analysis of the phenomenon of "non- State actors" playing on the Syrian scenario. Those actors, which have been firstly considered as internal rebel groups, secondly treated as terrorist groups, escalated in the last period of the conflict into a peculiar entity which threatens the international community acting as a "para-State" searching for a dangerous sort of legitimation. In view of this risk, the response of the UN Security Council has been uncertain so far and paved the way for new and serious
\end{abstract}

\footnotetext{
* Reflection article presenting the results of an investigation from an analytical and interpretative perspective of the main UN Security Council resolutions related to the violation of human rights, use of chemical weapons and terrorism in Syria.

a. Associate Professor and Dean of the College of Law at Royal University for Women, Kingdom of Bahrain. Barrister at Law, Ph. D. from University of Salerno, Italy with Master in Law of University of Rome "La Sapienza", Italy. Dr. Borea has been member of official delegations attending several international ministerial and governmental meetings in Europe and Middle East.
}

Pasquale Borea ${ }^{a}$ pasquale.borea@gmail.com Fecha de recepción: 01 de octubre de 2015 Fecha de revisión: 02 de octubre de 2015 Fecha de aceptación: 05 de octubre de 2015

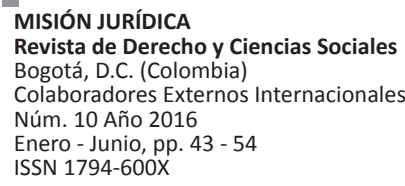


challenges for the international community which are highlighted by the article.

\section{KEY WORDS}

Human rights, chemical weapons, terrorist groups, "non- State actors", Security Council, Syria, international terrorism.

\section{RESUMEN}

El estudio sugiere una reflexión sobre las resoluciones del Consejo de Seguridad de la ONU, emitidos entre 2013 y 2015, en relación con el conflicto ocurrido en Siria. Se ofrece un análisis crítico de las diversas cuestiones tratadas en el Consejo de Seguridad y principalmente relacionados con la violación de los derechos humanos, el uso de armas químicas y el terrorismo. El análisis tiene en cuenta las principales teorías doctrinales del derecho internacional en relación con los tres principales argumentos tratados con una reflexión orientada al análisis del fenómeno de "actores no estatales" que juegan en el escenario sirio. Esos actores, que han sido considerados en primer lugar como grupos rebeldes internos, tratados en segundo lugar como grupos terroristas, se intensificaron en el último período del conflicto en una entidad peculiar que pone en peligro a la comunidad internacional que actúe como un "para-Estado" en busca de una especie peligrosa de legitimación. En vista de este riesgo, la respuesta del Consejo de Seguridad de la ONU ha sido incierta hasta el momento y allanado el camino para nuevos y graves retos para la comunidad internacional que se destacan por el artículo.

\section{PALABRAS CLAVE}

Derechos humanos, armas químicas, grupos terroristas, "actores no estatales", Consejo de Seguridad, Siria, terrorismo internacional.

\section{RESUMO}

0 estudo sugere uma reflexão sobre as resoluções do Conselho de Segurança da ONU, emitidas entre 2013 e 2015, em relação ao conflito ocorrido na Síria. Dispõe-se uma análise crítica das várias questões abordadas no Conselho de Segurança e, em especial, das relacionadas à violação dos direitos humanos, ao uso de armas químicas e ao terrorismo. A análise leva em conta as principais teorias doutrinais do direito internacional em relação aos três argumentos principais, por meio de uma reflexão orientada ao estudo do fenômeno de atores não estatais que interagem no cenário sírio. Esses atores, que foram considerados principalmente como grupos rebeldes internos e, em seguida, como terroristas, intensificaram-se no último período de conflito, em uma entidade peculiar que coloca em perigo a comunidade internacional que atue como um "para-Estado", em busca de um tipo arriscado de legitimação. Perante este risco, a resposta do Conselho de Segurança da ONU tem sido pouco clara até agora, abrindo caminho para novos e graves desafios à comunidade internacional, aspectos estes destacados neste artigo.

\section{PALAVRAS-CHAVE}

Direitos humanos, armas químicas, grupos terroristas, atores não estatais, Conselho de Segurança da ONU, Síria, terrorismo internacional.

\section{INTRODUCTION}

The present article aims at a critical analysis of the conflict in Syria from a point of view of the international law. It constitutes a point of view not related to political considerations or to the attribution of responsibilities to the parties in conflict, rather intends to contribute in providing a neutral reflection on the qualification of the Syrian conflict from the point of view of international law, mainly based on the interpretation of reports and resolutions issued by the United Nations. The article provides a reflection on the various resolutions adopted by the U.N. Security Council and related to the interpretation of the nature of the Syrian uprising, the use of chemical weapons and the emergence of non- State actors on the Syrian scenario.

\section{METHODOLOGY}

Developing the research, various methods of analysis and synthesis will be applied, using the interpretative approach for the main Security Council resolution issued in the last two years. The analytical method will be completed through a synthetic recall of the main doctrinal trend in the application of the international law doctrine to the main assumptions of the UN Security Council. The result is a reflection on the 
effectiveness of the Security Council resolutions in treating the problems related to international law, humanitarian law, the law of war and terrorism on the Syrian scenario.

\section{THE CLASSIFICATION OF THE CONFLICT IN SYRIA}

First of all, it is useful to investigate to which category the Syrian conflict pertains, according to the practice and to the main doctrines related to public international law ${ }^{1}$. Particularly, it is interesting to investigate if the Syrian uprising can be considered as internal conflict, international armed conflict or non- international armed conflict ${ }^{2}$. For the aforesaid purpose is useful to analyze the report submitted by the Independent Commission of Inquiry on Syria (ICIS) which has been entitled by the U.N. Human Rights Council to find any possible violation of human rights in Syria after the crisis has emerged throughout the country. The aforesaid committee has submitted two different reports and one followup report related to the human rights violations which have happened in Syria starting from March 2011. In the first report the ICIS has highlighted the concrete risk of degeneration from the status of internal conflict to the level of armed conflict under international law. This has been underscored notably after the establishment of the Free Syrian

1. For general references on international armed conflicts in Public International Law the literature is extremely wide. Among the various authors confront: Evans, M.D. (ed.) (2006). International Law. New York: Oxford University Press; Cassese, A. (2005). International Law. New York: Oxford University Press; Dupuy, P.M., Kerbrat Y. (2012). Droit International Public. Paris: Dalloz; Conforti, B. (2006). Diritto Internazionale. Napoli: Editoriale Scientifica; Panebianco, M. (2010). Manuale di Diritto Internazionale Pubblico. Napoli: Editoriale Scientifica; Sinagra, A., Bargiacchi, P. (2009). Lezioni di Diritto Internazionale Pubblico. Milano: Giuffre'; Monaco, R. (1960). Manuale di Diritto Internazionale Pubblico. Torino: UTET. With reference to the specific subject of the law of war and humanitarian law, the literature is extensive, among the various authors, refer mainly to: Best, G. (1980). Humanity in warfare. New York: Oxford University Press Best, G. (1994). War and Law since 1945. New York: Oxford University Press; Fleck, D. (ed.) (1995). The Handbook of Humanitarian Law in armed conflicts. New York: Oxford University Press, Green, L.C. (2000). The contemporary Law of armed conflicts, Manchester: Manchester University Press.

2. As far as the definition of international armed conflict and the application of humanitarian law see, among many other authors, Moir, L. (2000). The law of international armed conflicts. London: Cambridge University Press, 1-250; Crawford, J. (2012). Brownlie's Principles of Public International Law. New York: Oxford University Press, 744 - 774; Shaw, M. (2008). International Law. London: Cambridge University Press, 1118 - 1199; Panebianco, M. (2010) op. cit., 240 - 267; Tomuschat, C. (2014). Human Rights between idealism and realism. New York: Oxford Press, 291-318.
Army. The analysis of the nature of international conflict is essential to the present study since the qualification of the conflict as armed conflict regulated by the international law paves the way for the application of international humanitarian law. In fact, the repeated clashes between a regular army and other rebel groups not gathered into an independent, self-organized and structured armed group, characterizes an internal conflict regulated by the 1949 Geneva Convention (art.3) related to the minimum standards to be conferred to the parties involved in the hostilities. But the nature of the conflict as internal conflict implies, of course, the abstention of any third State from support to insurgents if the status of "belligerence" has not been declared by the legitimate authorities of the sovereign State. This is a consolidated principle in the doctrine which attributes to the sovereign States the definition of the legal status of rebel groups and it is, hence, strongly related to political considerations and to different and subjective interpretations from the single sovereign State. Where the conflict is merely internal and does not reach the level of non-international armed conflict, the internal turmoil is considered a threat to the legitimate sovereign authority of the State. In this case, the definition of armed conflict remains within the discretion of the sovereign State. As a consequence, the definition of non-international armed conflict, and the consequent application of humanitarian law, depends on the frequency and the intensity of the conflict as well as on the level of "organization" of rebel groups. It is a matter of fact that the ICIS report has correctly highlighted the consolidated interpretation of the International Court of Justice on the application of the human rights law during armed conflicts. Consolidated jurisprudence states that the law of armed conflict applies as lex specialis related to the conduct of hostilities ${ }^{3}$. The same report has underscored severe violations of human rights in different locations of the Syrian Arab Republic. But according to the second ICIS report, dated February 2012, the two elements

3. With reference to non-international armed conflicts, confront, among others Sivakumaran, S. (2012) The law of non-international armed conflicts. New York: Oxford University Press, 394-395; Moir, L. (2008). The historical development of the application of Humanitarian Law in non-international armed conflicts to 1949. International and Comparative Law Quarterly, 337, 353- 361; Sassoli, M. (2007). Ius ad bellum and Ius in bello - The separation between the legality of the use of force and humanitarian rules to be respected in warfare: Crucial or Outdated?. Essays in honour of Y Dinstein. Leiden: Brill Nijhoff, 240; Schmitt, M., Pejic, J. (2007) International Law and armed conflicts: exploring the faultlines. Essays in honour of Y Dinstein. Leiden: Brill Nijhoff, 243. 
characterizing a non-international armed conflict (intensity of clashes and level of "organization" of the two parties in conflict) were not clear. As a consequence, the application of the provisions of humanitarian law in the Syrian crisis was not free from possible objections.

The report has mentioned that several attacks against governmental military installations have had many and variegated responsibilities not limited to the Free Syrian Army. Whereas the responsibility for such acts was extended to civilians and deserters of the regular army. As a consequence, no clear proof or sufficient elements to demonstrate the coordination of the various opposition groups have been shown, in order to clearly define the Free Syrian Army as an "organization". These considerations are certainly not sufficient to define the Syrian conflict as a non-international armed conflict, according to the international law. The ICIS follow-up report, submitted in May 2012, has stressed the increased intensity of violence and an advanced level of organization of the anti- Government armed groups, affirming that only in some limited areas of the country the hostilities had reached the level of noninternational armed conflict according to the three criteria related to intensity, duration and organization of hostile groups. The consequent report of the U.N. Secretary General has stressed serious violations of human rights from both Governmental and AntiGovernment forces. On this background, it can be said that the Syrian conflict has been perceived from the international institutions as a conflict without rules in which it has been possible to highlight several and severe violations of human rights from both sides, without having the character of "war" with all the consequences on the applicable international provisions related to the law of war and humanitarian law, and the possible definition of war crimes.

Nevertheless, it can be affirmed, in tune with part of the doctrine ${ }^{4}$, that the facts which have been reported by the U.N. bodies involved, have demonstrated that there were sufficient elements to consider the Syrian events as a noninternational armed conflict, at least in the second phase of the hostilities.

4. Avenia, C. (2014). Il conflitto in Siria: spunti di riflessione ed analisi critica. Ordine Internazionale e Diritti Umani, 3/2014, 709- 755; Stahn, C. (2013). Syria. Security Council Resolution 2118 (2013) and peace versus justice: two steps forward, one step back. European Journal of International Law, Vol. 24, n.3, 2013.

\section{THE USE OF CHEMICAL WEAPONS AND HUMAN RIGHTS VIOLATIONS IN SYRIA}

These considerations are corroborated by some observations related to the use of chemical weapons in Syria as reported by investigations held at U.N. level and by the International Commission of the Red Cross (ICRC). Though there were no clear attributions of responsibilities for the use of such weapons, it is a matter of fact that such weapons have been used over Syrian territory and civilians. Since the international focus on the Syrian upraising has been increasingly enhanced because of the use of chemical weapons, it is useful to add few considerations about the possible violations of international law and international human rights law consequent to the use of chemical weapons.

The international law generally bans the use of chemical weapons since the chemical weapons are the core topic of several international treaties such as the 1993 Chemical Weapons Convention, the Statute of International Criminal Court, and the 1925 Protocol for the prohibition of the use in war of asphyxiating, poisonous or other gases and of bacteriological methods of warfare. The limit of the aforesaid international treaties is that the prohibition is applicable to the international armed conflicts only but not to those conflicts which do not have an international character, like the non-international armed conflicts ${ }^{5}$. Through the analysis of the above mentioned international treaties, it is easy to realize that Syria is not a contracting party of them (i.e. Syria is not a State party of the Statute of Rome for the establishment of the International Criminal Court) and even though Syrian Arab Republic is bound by the 1925 Protocol, the provisions of the same Protocol are binding for the State parties only. Consequently, this set of rules is not applicable to those conflicts in which one of the parties is a non-State (like rebels or non- Government forces are), so none of

5. With reference to the application of the prohibition of the use of chemical weapons in internal conflicts see: Blake, J., Mahmud, A. (2013). A legal red line? Syria and the use of chemical weapons in civil conflict. University of California Law Review, 61/2013, 256-257; See also the Advisory Opinion of the International Court of Justice on Legality of threat or use of chemical weapons, ICJ Reports 226, 245, par. 41.6. A partir deste momento, têm-se a positivação dos direitos tidos como inerentes ao homem, que, até dado instante, se encontravam mais afeicoados a reivindicacões políticas e filosóficas do que as normas jurídicas obrigatórias, exigíveis judicialmente. 
the parties involved in the Syrian crisis is legally bound by such provisions.

As far as the Chemical Weapons Convention is concerned, Syria joined the Convention in 2013 only, mainly for political reasons after the Russian mediation. The state parties to the Convention are bound by a general provision by which they undertake not to: develop, produce, otherwise acquire, stockpile or retain chemical weapons or transfer, directly or indirectly, chemical weapons to anyone; use chemical weapons; engage in any military preparations to use chemical weapons; assist, encourage or induce, in any way, anyone to engage in any activity prohibited to a State Party, etc. Furthermore, under the same Convention the State parties undertake to destroy the chemical weapons in its possession, and any related production facility. The provisions of the Convention ban the chemical weapons in their totality and the ban is extended to all the equipment and tools that are able to release chemical substances intentionally directed to harm humans. Furthermore, the range of the Convention is not limited to the ban of chemical weapons rather it requires further actions towards the nonproliferation of chemical weapons with severe restriction to the circulation of chemical substances and duty of inspection. Nevertheless, the general ban of use of chemical weapons according to the above mentioned Convention it is not something universally accepted and undisputed. The total ban of such chemical weapons as stipulated by the Chemical Weapons Convention should apply to all scenarios, regardless the character of internal or international conflict. This interpretation seems to be in contrast with the provisions stipulated in the Statute of the International Criminal Court which include the use of poison or poisoned weapons, asphyxiating and other chemical gases or materials in the definition of "war crimes". As a consequence, such ban should be applicable to "war", hence to international armed conflicts only. The prohibition of use of chemical weapons in internal armed conflicts still remains based on a "general consensus" of the international community which has been affirmed in few cases by the international jurisprudence ${ }^{6}$ but it is not a consolidated practice. According to the existing international Conventions it is self-evident that the use of chemical weapons in internal armed conflicts cannot be prohibited

6. In this respect, the "ad hoc" International Criminal Tribunal for former Jugoslavia, in the Tadič case embraced this principle. "sic et simpliciter" rather the use of chemical weapons on civilians may be qualified as a gross violation and considered a crime against humanity ${ }^{7}$, and consequently subjected to the universal jurisdiction. In this case the responsibility of the "individual-organs" shall be scrutinized and based on clear proof and on a specific resolution of the U.N. Security Council. Nevertheless, as above mentioned, Syria is not a State party of the Statute of Rome establishing the International Criminal Court. The aforesaid considerations clearly show how difficult is for the international law to provide an effective and appropriate remedy to the violations perpetrated in Syria.

Following the track of U.N. bodies, it is useful to mention that the ICIS submitted a final report in 2013. This report introduces a brand new interpretation of the ban of chemical weapons. The report considers any use of chemical weapons, whether used during international armed conflicts or not, a threat to the international peace and security paving the way for a new approach towards the illegal use of chemical weapons to be extended to the internal conflicts also. Based on the aforesaid reports, the U.N. Security Council unanimously passed a resolution stressing the ban of chemical weapons. The resolution $(2118 / 2013)$ on the one hand reaffirms the ban of chemical weapons and reinforces the international mechanisms for the elimination of chemical arsenals, on the other hand shows a relevant lack from the point of view of international law ${ }^{8}$. Indeed, the resolution is not based on the provisions stipulated in chapter VII of the U.N. Charter, with a consequent impact on the possible sanctions in case of violations. Furthermore, the resolution does not attribute any clear responsibility for the violations committed in the Syrian conflict to the Syrian government neither to the rebel forces. As a consequence, the U.N. Security Council response is affected by a clear weakness, since it does not

\footnotetext{
7. Regarding "internal" armed conflicts and humanitarian law, confront also: Bothe, M. (1978). Conflits armés internes and droit international humanitaire. Revue Generale de Droit International. 82, 92-93.

8. Jacobsson, M. (2014), A snapshot of legal time-frame: The United Nations Security Council Resolution 2118 (2013) and the OPCW Executive Council decision. Ebbesson J. (ed.), International Law and changing perceptions of security : liber amicorum Said Mahmoudi, Leiden: Brill Nijhoff, 134-151. so de Direito Constitucional. 2a.ed. São Paulo: Revista dos Tribunais, 2013. p.539.
} 
identify the use of chemical weapons on civilians as a crime against humanity and it does not contain any appeal to ceasefire. Therefore it is clear that, persisting a lack in attributing precise responsibilities for the use of chemical weapons, the U.N. Security Council resolution remains an empty box. From a different perspective, it can be certainly affirmed that the U.N. "system" proved that chemical weapons have been used during the Syrian conflict, but it did not prove any responsibility for the deployment and use of such weapons. The investigations of the independent committee have found proofs of use of chemical weapons against civilians but have not been able to ascertain clear responsibilities for the facts which have been, in any case, defined "a threat to the international peace and security".

Despite the lack of effectiveness, it is interesting to analyze the resolution 2118 (2013) form another point of view. The document contains some interesting considerations on the responsibility of nonState actors in the use of chemical weapons. The resolution clearly states that the use of chemical weapons by any party shall be considered a threat of the international peace and security. As a consequence, the resolution stressed the accountability of those entities (States or non-state actors) responsible for any use of chemical weapons. It is interesting to note that the Security Council demands ${ }^{9}$ to the non-State actors not to develop or possess or use chemical and biological weapons.

This "trend" about the possible accountability of non-State actors for the use of chemical weapons ${ }^{10}$ could pave the way for a recognition of such actors in order to consider them bound by international duties and, as a

9. U.N. Security Council Resolution 2118, 27th September 2013, Paragraph 19: Demands that non-State actors not develop, acquire, manufacture, possess, transport, transfer or use nuclear chemical or biological weapons and their means of delivery, and calls upon all Member States, in particular Member States neighbouring the Syrian Arab Republic, to report any actions inconsistent with this paragraph to the Security Council immediately. Retrived from http://www.un.org/ press/en/2013/sc11135.doc.

10. With reference to the applicability of human rights law to nonState actors confront: Tomuschat, C. (2004). The applicability of Human Rights Law to insurgent movement. Fisher, H., Froissrt, U., Heintshel Von Heinegg, W., Rapp, C., Crisis management and humanitarian protection, Berlin: Wissenshaft Verlag, 573. consequence, to benefit from some rights. In this respect, it is indeed quite hard to embrace this interpretation since it is difficult as well as extremely dangerous to consider such nonState actors as subjects of international law. This does not mean that those groups shall not restrain from using chemical weapons or perpetrating other violations of human rights, but such groups cannot be legitimated as international subjects for a number of reasons. The first reason is a political reason by which the international community cannot accept or recognize such groups as State actors because of the blatant violations of jus cogens principles, moreover, as previously stated, the Free Syrian Army, as well as other groups, cannot meet the criteria to be considered an independent and organized group. The Syrian opposition, and within that the Free Syrian army, is a melting pot of variegated organizations, with different backgrounds and different reasons to oppose Assad's government. Furthermore, as already highlighted above, these groups do not show the typical criteria and levels of organization which are able to qualify the groups as an organized army. As a consequence, for the above mentioned reasons also, the Syrian conflict cannot be considered an international armed conflict, with all the limitations related to this situation. Similar considerations are of course involved in the possible identification of a responsibility for the use of chemical weapons against civilians. In this respect, the U.N. Security Council resolution does not identify a clear and sole responsibility for the use of chemical weapons on Syrian territories, since there are elements to connect the responsibility for the use of such weapons to the both hostile parties. The conclusion of the U.N. resolution is limited to a call for cooperation from both parties from a humanitarian point of view.

This obviously complicates the interpretation of the U.N. structure on the Syrian uprising. If on the one hand there are not sufficient elements to consider the conflict as an international armed conflict, on the other hand there is a call for humanitarian aid in contrast with the usual approach towards those conflicts, not prolonged and not defined as "international conflicts", for which the international law does not require any humanitarian intervention. 


\section{TERRORISM, FOREIGN FIGHTERS AND NON- STATE ACTORS IN THE SYRIAN SCENARIO}

Due to this situation, a different trend emerged within the international doctrine $\mathrm{e}^{11}$, providing a different interpretation of the case. The emergence of the so called "responsibility to protect" has been considered one of the possible solutions for the Syrian crisis. Although this approach, out of the cases of international conflicts, seems in contrast with the general principle of non-interference in internal affairs, the U.N. Security Council stressed the degeneration of the humanitarian situation in its Resolution 2139 dated 22 February 2014. This document demands both parties to cease all attacks against civilians and to desist from all forms of violence and abuses of human rights. Once again, there is no clear blame for responsibilities but the decision of the Security Council is more focused on the humanitarian aspect, demanding to allow delivery of humanitarian aid, urging "all Member States, based on burden-sharing principles, to support the neighboring host countries to enable them to respond to the growing humanitarian needs, including by providing direct support". Furthermore, for the first from the beginning of hostilities in Syria, the Security Council expressly worries about the terrorist attacks and strongly condemns the presence of individuals and organizations, apparently not related to the parties in conflict. Moreover for the first time the Security Council highlight and condemns the presence of "foreign fighters" on Syrian scenario, demanding "that all foreign fighters immediately withdraw from Syria, and reaffirms that terrorism in all its forms and manifestations constitutes one of the most serious threats to international peace and security, and that any acts of terrorism are criminal and unjustifiable, regardless of their motivation, wherever, whenever and by whomsoever committed".

Nevertheless, the presence of foreign fighters and non-State actors on Syrian territories is still not expressly qualified by the U.N. Security Council as a threat to the international peace and security. The resolution 2139 remains basically

11. Avenia, C., op. cit, 744; Bannon, A.L. (2006). The responsibility to protect: the UN World Summit and the question of multilateralism. Yale Law Journal, 115; Glanville, L. (2010). The international community's responsibility to protect. Global Responsibility to Protect, (2), 287-306; Crawford, J. (2012). op.cit., 755 - 757; Blewitt, R. (2013 December), The United Nations in Syria and the responsibility to protect. Caribbean Journal of International Relations and Diplomacy, 1 (4), 39-47. focused on the humanitarian intervention in the conflict which is again, as above widely argued, something questionable if the conflict is analyzed through the lens of international law of war.

A further resolution dated 14th July 2014 (2165) reiterates the need of delivery of humanitarian assistance and the need for the parties in conflict, in particular the Syrian authorities, to comply with their obligations under international humanitarian law and international human rights law. But it is only through the Resolution 2170, dated 15th August 2014, that the Security Council decides to focus on non-State actors on the Syrian scenario using the powers conferred by Chapter VII of the U.N. Charter. In fact, the resolution's final aim is to impose sanctions to some individual leaders of the Daesh ${ }^{12}$ or ISIS and Al Nusrah Front by the inclusion of their names in the terrorist's black list. The intention of the Security Council is to demonstrate the common front of the international community in banning such terrorist groups operating as non- State actors on Syrian territories. The solution adopted by the Security Council is to provide a unified response of the international community to the violent escalation of such groups through the same means used to contain the Al Quaeda terrorist actions as per the Security Council resolution 1373 (2001). The U.N. response is of course blatantly tardive and limited to the confirmation of the obligations requested to the member States by previous resolutions. It seems to be correct the interpretation

12. The western world is more familiar to the term ISIS or IS. The Islamic State in Iraq and Syria (ISIS) or Islamic State in Iraq and the Levant (ISIL), Islamic State in Iraq (ISI), or simplified in Islamic State (IS) is known in the Arab World by the acronym DAESH (ش), which omits references to "Islamic" in their Arabic name ماشل, ad-Dawlah al-Islāmìyah fil 'Irāq wa ash-Sh̆àm, roughly "The Islamic State in Iraq and Greater Syria". The group originated as Jama'at al-Tawhid wal-Jihad in 1999, which was renamed Tanzim Qaidat al-Jihad fi Bilad alRafidayn-commonly known as al-Qaeda in Iraq (AQI)-when the group pledged allegiance to al-Qaeda in 2004. As Jama'at and later AQI, the group participated, from August 2003, in the Iraqi insurgency which had followed the March 2003 invasion of Iraq. In January 2006, it joined other Sunni insurgent groups to form the Mujahideen Shura Council, which in October 2006 proclaimed the formation of the Islamic State of Iraq (ISI). Under the leadership of Abu Bakr Al-Baghdadi, ISI sent delegates into Syria in August 2011 after the Syrian uprising had begun in March 2011. This offshoot named itself Jabhat an-Nușrah liAhli ash-Shām or al-Nusra front and established a large presence in Sunni-majority areas of Syria within the governorates of Ar-Raqqah, Idlib, Deir ez-Zor and Aleppo. Having thus expanded into Syria, Al-Baghdadi announced the merger of his ISI with his Syrian-based offshoot-group al-Nusra Front in April 2013, and changed the name of the reunited group to Islamic State of Iraq and the Levant (ISIL). 
of part of the doctrine ${ }^{13}$ according to which the resolution 2170 does not show the intention of eradicating a specific threat to the international peace and security, represented by the emergence of non- State actors ${ }^{14}$, rather to face an "abstract" and theoretical phenomenon identified with the word "foreign fighters". The Security Council does not focus on the specific situation of Syria and North Iraq, rather recalls previous resolutions in order to impose to the U.N. member States obligations to provide a general countermeasure to international terrorism, focusing mainly on the contrast to the financial flows to the groups and the contrast to the mobility of the individuals.

This approach is confirmed by the following Security Council resolution 2178 dated 24th September 2014. As far as the legitimation of the resolution under Chapter VII of the U.N. Charter is concerned, the preamble of the above mentioned resolution seems to confirm the vague and too general approach to the problem. The preamble of the resolution stresses "the continued threat to international peace and security posed by terrorism" and affirms «the need to combat by all means, in accordance with the Charter of the United Nations, threats to international peace and security caused by terrorist acts, including those perpetrated by foreign terrorist fighters". The resolution highlights legally binding obligations to the member States which are requested to "prevent and suppress the recruiting, organizing, transporting or equipping of individuals who travel to a State other than their States of residence or nationality for the purpose of the perpetration, planning, or preparation of, or participation in, terrorist acts or the providing or receiving of terrorist training, and the financing of their travel and of their activities".

On these bases, it is clear that the resolution 2178 (2014) is part of the trend adopted by the Security Council with previous resolutions aiming at a fighting

13. Cadin, R. (2014). Il Consiglio di Sicurezza torna a legiferare nella risoluzione 2178 (2014) si "combattenti terroristi stranieri". Osservatorio sul consiglio di sicurezza ed i diritti umani n.4/2014. Ordine Internazionale e diritti umani. Retrived from: http://www.rivistaoidu.net

14. The phenomenon of non-State actors is not new to the international doctrine. For a general reference see: Clapham, A. (2006), Human Rights obligations of non-State actors. New York. Oxford University Press, XV-601. Regarding the non-State actors in conflict situations see Clapham, A.(September 2006). Human Rights obligations of non-State actors in conflict situations. International Review of the Red Cross. 88 (863), 491-523. the international terrorism through a generalized "emergency approach" rather than a specific and targeted action towards single and different cases of threat of the international peace and security. In other words, the Security Council seems not able to distinguish the different nature of Daesh and $\mathrm{Al}$ Qaida, nor the different contest and magnitude, with a consequent weakness of its binding decisions adopted under Chapter VII of the U.N. Charter.

The Security Council has limited its response to the phenomenon of non-State actors in Syria to the two above mentioned resolutions, providing a late and weak response. Indeed, the next steps which followed the resolutions 2170 (2014) and 2178 (2014) are, once again, more focused on the humanitarian aspects rather than the qualification of the conflict and the analysis of the new phenomenon of non- State actors.

The resolution 2191, dated 17th December 2014, again focuses on the humanitarian aspect of the happening, recalling the previous resolutions 2139 (2014) and 2165 (2014) underscoring the total lack of implementations of the provisions therewith recommended. The resolution indeed it is a mere renewal of what stipulated in the previous resolution 2165 (2014) for a period of twelve months regarding the delivery of humanitarian assistance. The resolution is certainly not attributable to the framework of Chapter VII of the Charter and the hoped implementation of the provisions aiming at ensure the delivery of humanitarian assistance still remains inadequate so far.

With resolution 2199, dated 12th February 2015, the Security Council embraces again Chapter VII of the Charter and issues a resolution aiming at the contrast of ISIL and Al Nusra funding through oil exports, traffic of cultural heritage, ransom payments and external donations. Again, the Security Council's action seems to be undoubtedly tardive in contrasting non-State actors, such as ISIL and $\mathrm{Al}$ Nusra front, which have already acquired an extremely dangerous dimension in controlling oil fields, infrastructures and power plants.

\section{THE SECURITY COUNCIL ULTIMATE STEPS: THE 2015 RESOLUTIONS}

Amongst the various Security Council's resolutions, fluctuating between the affirmation and sanction of human rights' violations, contrast to terrorist groups and use of chemical weapons, 
there is no clear direction and no resoluteness in dealing with the Syrian conflict. After issuing the resolution under Chapter VII dated February 2015, the Security Council recalls the theme of chemical weapons in its resolution 2209 (2015) dated 6th March 2015. Nonetheless, the resolution is again a very general statement in which there is no clear blame on the conflicting parties regarding the use of chemical weapons.

Furthermore, the resolution does not impose any new action rather recalls the resolution 2118 (2013) without focusing on the problem of the application of the CWC to internal conflicts. Moreover the resolution does not adopt measures under Chapter VII of the Charter but limits itself to consider "in the events of future non- compliance with resolution $2118^{\prime \prime} 15$ to impose measures under Chapter VII of the Charter. The same statement is found in item 15 of the following resolution 2235 (2015) dated 7th August 2015. The resolution 2235 constitutes the last action undertaken by the Security Council so far. The resolution, once again is not issued under the framework of Chapter VII of the Charter and again it focuses on the use of chemical weapons and particularly on the role of Organization for the Prohibition of Chemical Weapons (OPCW). Particularly, the OPCW, as above mentioned, had been requested by the Security Council in its resolution 2118 (2013) to report on non-compliance with the aforesaid resolution through a fact finding mission. The OPCW still in February 2015 had reported about the findings which showed with high level of confidence that chlorine has been used repeatedly and systematically as a weapon over Syrian territories.

Of course, as reiterated in the same resolution 2235, the OPCW did not have the mandate to reach conclusions about the attribution of responsibilities in using chemical weapons, rather just to confirm if such weapons were used in Syria. So again the Security Council does not reach an affirmation of responsibilities for the use of chemical weapons and, as a consequence does not issue any measure under Chapter VII, but requests the establishment of an "OPCW-U.N.

15. In item number 7 of the Resolution 2209 (2015) the Security Council "Recalls the decisions made by the Security Council in resolution 2118, and in this context decides in the event of future non-compliance with resolution 2118 to impose measures under Chapter VII of the United Nations Charter".
Joint Investigative Mechanism" to identify responsibilities. This happens two years later the adoption of the first resolution 2118 in September 2013. Once again, promptness in adoption of counter measures by the Security Council seems to be faraway. The resolution 2235 requests the U.N. Secretary General and the OPCW Director General to "submit to the Security Council, for its authorization, within 20 days of the adoption of this resolution, recommendations, including elements of Terms of Reference, regarding the establishment and operation of an OPCW -United Nations Joint Investigative Mechanism to identify to the greatest extent feasible individuals, entities, groups, or governments who were perpetrators, organizers, sponsors or otherwise involved in the use of chemicals as weapons, including chlorine or any other toxic chemical, in the Syrian Arab Republic where the OPCW FFM determines or has determined that a specific incident in the Syrian Arab Republic involved or likely involved the use of chemicals as weapons, including chlorine or any other toxic chemical". Hence, a time frame is scheduled in order to establish a body that will be entitled to identify responsibilities related to the use of chemical agents. Only after the authorization of the Joint Investigative Mechanism by the Security Council, investigations will start and evidences collected by the newly established body will be transmitted to the U.N. Secretary General.

As a result any imposition of measures under Chapter VII by the Security Council is submitted to the evidences found by the Joint Investigative Mechanism.

At the time of the present research ${ }^{16}$, resolution 2235 constitutes the last resolution issued by the Security Council on the Syrian conflict.

\section{CONCLUSIONS: WEAKNESS OF THE SECURITY COUNCIL RESOLUTIONS AND NEW CHALLENGES FOR THE INTERNATIONAL COMMUNITY}

As a conclusion it can be certainly affirmed that the Security Council response to the Syrian crisis has not been effective at all. Lack of

16. This research has been finalized and submitted in the end of September 2015. 
promptness, confusion, alternation in different approaches to the different problems related to the maintenance of international peace and security have certainly distinguished the response of the collective security system regarding Syrian happenings. This situation is certainly due to political decisions which have been reflected in the Security Council balance of powers, especially regarding the permanent member States. All this inevitably brings to the attention of international observers the urgent need for a thorough reflection on the collective security system, its effectiveness, and the related need for a reform of the U.N. Security Council's structure. The problem is not new, rather the Syrian crisis is the umpteenth example of a crisis of the U.N. system that largely paved the way for the more frequent recourse to unilateral interventions in a large number of scenarios during the last few years which is surely something not beneficial for the preservation of peace and security on the international scenario. All this has certainly an impact, generally speaking, on the phenomenon of "failed States" in post crisis scenarios. At this stage, the situation in Syria seriously affected the institutional functions and administrative duties of the State. Regardless the qualification of the conflict, regardless the responsibility for the use of chemical weapons and the violation of human rights, the most critical aspect of the Syrian crisis is the impossibility of guarantee an effective government to the country. From a political point of view it seems hard to find an alternative to the Assad's government, on the other hand the menace of non- State actors that aim to represent themselves as governing entities and seek international legitimation is the main threat for the international stability. The international community and the U.N. Institutions above all, will face soon or later the challenge of dealing with a State structure that needs to be reconstructed. In this respect, it could be interesting the reflection on the interpretation emerged during the last "Manama Dialogue" Regional Security Summit ${ }^{17}$ by which some official representatives of different countries agreed upon the theory of "failed States" as a flexible theory. This approach

17. December 5th - 7th 2014, Manama, Kingdom of Bahrain. The Manama Dialogue is an annual conference on Regional Security organized by the International Institute for Strategic Studies. It gathers together high-level national delegations of Ministries of Interiors, Defense and Foreign Affairs, in order to provide an informal platform for discussing regional security issues in Middle East. is not new to the doctrine and it focuses on the different definitions of "failed States" and "fragile States". According to this approach, the "failed State" is incapable to ensure the protection of its own community and it is not able to ensure the performance of normal institutional affairs and the basic administrative duties of a sovereign State. These kinds of States, which experienced a collapse of their institutional assets, are considered unable to control their territories and incapable to guarantee the minimum standard in terms of security and assistance to the population. In these cases the foreign intervention based on humanitarian aid is considered necessary. On the other hand, the "fragile State" shows three basic gaps in terms of security, capacity and legitimacy. The approach of the international cooperation towards these kind of States should not be based on security and military cooperation only, rather it should be enlarged to other fields of foreign cooperation related to many other administrative sectors from health to education. The risk of the approaches limited to provide security cooperation is to create a "dependence" from foreign aid in terms of security. According to the aforesaid criteria, Syria should not be considered a "failed State" rather a "fragile State" due to the fact that the institutional architecture of the State is not dissolved but weakened by the hostilities with non-governmental groups. This "new trend" in the interpretation of international legal principles imposes a serious reflection for the international doctrine which is called to face new and more complicate challenges related to the concept of collective security. All the exiting international treaties and all the measures related to the international human rights law ${ }^{18}$ do not take into consideration the character of "non-State" actors of some of the organizations which are currently responsible of the great part of violations in the Middle East region as well as internationally. The question which shall be raised on the international scenario is, hence, the following: how the international security intends to deal with non- State actors, when these entities are violating international rules, without being subjects of international law? The

18. De Shutter, O. (2009). International Human Rights Law. London, Cambridge: University Press, 7-250; Moeckli, A. (2010). International Human Rights Law. New York: Oxford University Press,29-112; Casey Maslen, S. (2013). Weapons under international human rights law. New York: Oxford University Press Press, 2- 85. 
answer is not easy, since the risk of conferring international subjectivity to these kind of groups might be an implicit legitimation, which shall not happen. And, of course, such a solution is not beneficial at all for the sake of international peace and security. Furthermore, it is also true that the system of "collective security" might be called very soon to face non-State actors which are already responsible of many international violations. This problem is not new to the international community, but after the Syrian uprising and, especially after the development of the ISIS menace, this becomes the most recent challenge for the international collective security system and for the development of an effective system of global protection of human rights. The approach of the international community to this new challenge shall be oriented to the coordination of the efforts towards the global menace of terrorist groups which are, in most of the cases, represented by non-State actors. Some proposals have already been tabled: from the institution of an international counterterrorism authority to the implementation of international cooperation towards a comprehensive, global strategy against terrorism. The challenge is open for States, regional groups of States and international organizations, above all the United Nations which in the latest Syrian crisis demonstrated once again its total lack of effectiveness and capability to contrast threats to the international peace and security.

\section{BIBLIOGRAPHIC REFERENCES}

- Avenia, C. (2014). Il conflitto in Siria: spunti di riflessione ed analisi critica. Ordine Internazionale e Diritti Umani, 3/2014, 709- 755.

- Bannon, A.L. (2006). The responsibility to protect: the UN World Summit and the question of multilateralism. Yale Law Journal, 115.

- Best, G. (1980). Humanity in warfare. New York: Oxford University Press, VI- 400.

- Best, G. (1994). War and Law since 1945. New York: Oxford University Press V-456.

- Blake, J., Mahmud, A. (2013). A legal red line? Syria and the use of chemical weapons in civil conflict. University of California Law Review, 61/ 2013, 256-257.

- Blewitt, R. (2013 December), The United Nations in Syria and the responsibility to protect. Caribbean Journal of International Relations and Diplomacy, 1 (4), 39-47.

- Bothe, M. (1978). Conflits armés internes and droit international humanitaire. Revue Generale de Droit International. 82, 92-93.

- Cadin, R. (2014). Il Consiglio di Sicurezza torna a legiferare nella risoluzione 2178 (2014) si "combattenti terroristi stranieri". Osservatorio sul consiglio di sicurezza ed $i$ diritti umani n.4/2014. Ordine
Internazionale e diritti umani.

- Casey Maslen, S. (2013). Weapons under international human rights law: London, Cambridge University Press, X-613.

- Cassese, A. (2005). International Law. New York: Oxford University Press, V-529.

- Clapham, A. (2006), Human Rights obligations of non- State actors. New York. Oxford University Press, XV-601.

- Clapham, A. (2006). Human Rights obligations of non-State actors in conflict situations. International Review of the Red Cross. 88 (863), 491-523.

- Conforti, B. (2006). Diritto Internazionale. Napoli: Editoriale Scientifica, V-405.

- Crawford, J. (2012). Brownlie's Principles of Public International Law. New York: Oxford University Press, VI- 775.

- De Shutter, O. (2014). International Human Rights Law. London: Cambridge University Press, XI- 1041.

- Dupuy, P.M., Kerbrat, Y. (2012). Droit International Public. Paris: Dalloz, VII- 919.

- Ebbesson J.(ed.) (2014), International Law and changing perceptions of security. Liber amicorum Said Mahmoudi, Leiden: Brill Nijhoff, XI- 350.

- Evans, M.D. (ed.) (2006). International Law. 
New York: Oxford University Press; 3- 825.

- Fisher, H., Froissrt, U., Heintshel Von Heinegg, W., Rapp, C., Crisis management and humanitarian protection, Berlin: Wissenshaft Verlag XI-382.

- Fleck, D. (ed.) (1995). The Handbook of Humanitarian Law in armed conflicts. London: Oxford University Press, XI- 585.

- Glanville, L. (2010). The international community's responsibility to protect. Global Responsibility to Protect, (2), 287-306.

- Green, L.C. (2000). The contemporary Law of armed conflicts, Manchester: Manchester University Press, V-416.

- Moeckli, A. (ed.) (2010). International Human Rights Law. New York: Oxford University Press, XXVI- 643.

- Moir, L. (2002). The law of international armed conflicts. London: Cambridge University Press, VII- 298.

- Moir, L. (2008). The historical development of the application of Humanitarian Law in non-international armed conflicts to 1949. International and Comparative Law Quarterly, 337, 353- 361.
- Monaco, R. (1960). Manuale di Diritto Internazionale Pubblico. Torino: UTET, XX-639.

- Panebianco, M. (2010). Manuale di Diritto Internazionale Pubblico. Napoli: Editoriale Scientifica, XI- 540.

- Schmitt, M., Pejic, J. (2007) International Law and armed conflicts: exploring the faultlines. Essays in honour of Yorim Dinstein. Leiden: Nijhoff, VII- 640.

- Shaw, M. (2008). International Law. London: Cambridge University Press, 3- 825.

- Sinagra, A., Bargiacchi, P. (2009). Lezioni di Diritto Internazionale Pubblico. Milano: Giuffre', 1-645.

- Sivakumaran, S. (2012). The law of noninternational armed conflicts. New York: Oxford University Press, XIX- 619.

- Stahn, C. (2013). Syria. Security Council Resolution 2118 (2013) and peace versus justice: two steps forward, one step back. European Journal of International Law, Vol. 24, n.3, 2013.

- Tomuschat, C. (2014). Human Rights between idealism and realism. New York: Oxford University Press, XVII- 391. 